\title{
Občanská rezistence indiánského, černošského a mestického obyvatelstva v Kolumbii
}

\author{
Klára Kleňhová
}

DOI: 10.21104/CL.2018.1.04

Civil Resistance of Indigenous, Black and Mestizo People in Colombia

\author{
Abstract This article is focused on the \\ specific kind of collective action called \\ civil resistance which is one of the most \\ explored themes in contemporary \\ Colombian academic research. The article \\ consists of three case studies which \\ show how this phenomenon has been \\ realized by communities who live in the \\ state's unprotected areas of Colombia. \\ Each of these communities represents \\ a different ethnic group of the Colombian \\ state (indigenous Nasa, Afro-Colombian \\ communities from river Yurumanguí \\ and mestizo people from river Ariari) as \\ well as different types of civil resistance. \\ The goal of this thesis is not only to \\ specify the type of peace initiative of \\ each particular community, but also to \\ find shared characteristics which could \\ represent the original common cause \\ of the creation of civil resistance.
}

Keywords Armed conflict, civil resistance, collective action, Columbia, peace initiative, Nasa, Afro-Colombian.

Práce byla napsána v rámci řešení projektu specifického výzkumu podpořeného studentskou grantovou soutěží FF UHK v roce 2014.

Contact Mgr. Klára Kleňhová, Filozofická fakulta Univerzity Hradec Králové, nám. Svobody 331, 50002 Hradec Králové, Czech Republic; e-mail: klenhovak@gmail.com.

Jak citovat / How to cite Kleňhová, Klára. (2018). Občanská rezistence indiánského, černošského a mestického obyvatelstva v Kolumbii. Český lid 105, 67-86. doi:http://dx.doi.org/10.21104/CL.2018.1.04 
Specifickou vlastností většiny latinskoamerických států je jejich omezená kapacita ve výkonu moci v některých částech svých rozsáhlých území, kde mají často nadvládu nestátní aktéři. V případě Kolumbie se jedná o levicové guerilly (zejména FARC, ELN), ${ }^{1}$ paramilitares, drogové kartely či nově vzniklé tzv. kriminální bandy (bandas criminales, bacrim). Vzájemné konfrontace kolumbijského státu s těmito skupinami vyústily do dlouholetého a velmi násilného ozbrojeného konfliktu, jehož největší obětí se stalo řadové obyvatelstvo, pro které se vykonávání spravedlnosti, veřejný prostor a služby postupem času staly prázdným pojmem. Za ztrátou legitimity státu a jeho oslabení totiž nestáli už pouze tito aktéři, nýbrž i aliance tvořené jimi a politiky. Jedním z aspektů těchto spojenectví, mezi nimiž je nejznámějším jevem parapolítica, ${ }^{2}$ je zastrašování řadových obyvatel, jejich vnitřní vysídlení, spoluúčast politiků na masakrech či selektivních vraždách nebo uvolňování peněz z veřejných zdrojů za účelem financování činnosti ilegálních ozbrojených skupin. Financování těchto aktérů však neplyne pouze z veřejných prostředků, nýbrž i skrze pašování zbraní, praní špinavých peněz či pěstování a obchodování se zakázanými plodinami, což dalo v Kolumbii popud ke vzniku dalšího fenoménu, a to tzv. narkoterorismu (González 2010: 37-38).

Z výše uvedeného vyplývá, že v kolumbijské společnosti existuje řada jevů, které podkopávají vznik suverénního státu, konstrukci míru, existenci solidní občanské participace a principy demokracie, jež je považována za jednu z nejdelších a nejstabilnějších demokracií v Latinské Americe. Předpokladem pro její prohloubení měla být Ústava z roku 1991, která sice posílila institucionální rozvoj demokratického politického systému, ale ve skutečnosti se o demokracii nedá hovořit, nebot zkušenost s ní se redukuje pouze na volební procedury. V rámci takové podoby demokracie mají občané sice možnost ve volbách participovat, ale jsou pod silným tlakem, který na ně vyvíjejí ozbrojení aktéři. Také politici jsou podrobeni nátlakům ze strany ozbrojených skupin, a to ve formě vyhrožování, únosů a vražd. Po volbách, tedy během administrativního období, se politika navíc nese v duchu klientelismu a korupce, která zapř́ičiňuje politické vyloučení zbytku společnosti (González 2010: 38-39).

Jelikož se samotnému státu nepodařilo tyto problémy odstranit, vznikly v mnoha částech Kolumbie občanské iniciativy, které přímo či nepřímo podporují vytváření míru a rozvoj demokracie a občanské participace v této zemi. Bylo to právě kolumbijské obyvatelstvo, co se pod tíhou teroru mnohokrát ozbrojenému konfliktu postavilo a užilo nenásilných civilních metod $\mathrm{k}$ obraně. Mnohé $\mathrm{z}$ těchto iniciativ rovněž usilují o snížení vlivu nadnárodních 
společností v různých regionech Kolumbie či o skoncování strukturálního konfliktu v zemi, nebot' se tento stát navzdory rychlému ekonomickému růstu potýká s velmi vysokým stupněm nerovnosti př́jmů u obyvatel a početně slabou střední třídou.

Příkladů mírových iniciativ v Kolumbii je mnoho a přicházejí od různých skupin obyvatel (vesničané, afrokolumbijské a indigenní komunity, ženy, pedagogové, i děti) a organizací (nadace, odbory, spolky, sněmy či asociace). Najdeme zde také různé projevy občanské rezistence jako pochody, fóra, vyjednávání o propuštění unesených, semináře, odmítání vnitřního vysídlení, vzpomínkové akty apod. Tyto variace občanské rezistence svědčí o tom, že se jedná o komplexní fenomén, který můžeme zkoumat různými způsoby a z různých úhlů pohledu. Náplní tohoto článku však není snaha o vytvoření typologie či určování typů jednotlivých projevů občanské rezistence v kolumbijské společnosti (byt i na tento aspekt bude během článku poukázáno). Tato práce, která bude mít podobu empiricko-analytické studie, bude věnována hledání příčin vzniku úspěšné občanské rezistence, a to konkrétně u tř́ skupin obyvatel. Ty byly vybrány na základě následujících kritérií:

1. Musí se jednat o iniciativy vzniklé na úrovni komunit.

2. Každá ze zkoumaných skupin obyvatel př́ísluší k jinému etniku.

3. Mezi vybranými komunitami budou pouze ty, které se nacházejí v periferních částech země a státní aparát má zde jen omezenou moc.

4. Vybrané komunity musely čelit jak strukturálnímu, tak ozbrojenému konfliktu, proti kterému úspěšně zakročily civilní cestou.

5. Musí se jednat o iniciativy s dlouhodobou trajektorií.

První zkoumanou skupinou je afrokolumbijská komunita žijící v okolí řeky Yurumanguí, která se nachází v departementu Valle del Cauca. Druhou skupinou jsou vesničané regionu Ariari z departementu El Meta, kde převládají obyvatelé mestického původu. Mírové iniciativě kmene Nasa, který je příslušníkem indigenní ${ }^{3}$ populace v severní části departementu Cauca, byla věnována poslední př́ípadová studie.

Tyto tři skupiny obyvatel patř́i do jednoho kulturně, historicky a politicky vymezeného prostoru, kterým je kolumbijský stát. Všechny, jak už z kritérií vyplývá, se rovněž úspěšně podílely na občanském vzdoru proti strukturálnímu a ozbrojenému konfliktu a jejich iniciativy mají dlouhodobou trajektorii. Takový druh iniciativ vykazuje jasnou politickou vizi a představu o tom,

3 V textu se vyhýbám užívání pojmu indián, který je sice v českém jazyce hluboce zakořeněn a konvenčně přijímán, avšak obzvláště v latinskoamerickém kontextu je tento termín, jehož původ vychází ze slova indio, silně koloniálně zatížen. Proto jsem se pro označení původních skupin obyvatel rozhodla v tomto článku pracovat s výrazem indigenní, nebot' se domnívám, že se jedná o nejbližší možný ekvivalent pojmu z hispanofonního slova indígena či anglofonního termínu indigenous. 
jak budovat mír a realizovat demokracii. Jeho představitelé dokáží strukturovat své zájmy a tvoří trvalé sněmy, spolky, asociace či hnutí (González 2010: 41). ${ }^{4}$

Při zkoumání však nesmíme podcenit faktory, kterými se od sebe dané komunity odlišují. Odlišnosti jak v etnicitě, geografii, historickém vývoji, tak v oblasti sociální, ekonomické, kulturní i politické umožňují položit si otázku, co bylo všem těmto komunitám natolik společné, že docílily úspěšné občanské rezistence. Proto bych ráda na základě Millovy metody shody chtěla najít společné okolnosti, které by mohly být považovány za příčiny vzniku zkoumaného jevu, tedy občanské rezistence.

K nalezení těchto okolností, ale i k určení typu každé z iniciativ, mi posloužily jak sekundární, tak primární zdroje, které jsem podrobila analýze. Primárními zdroji informací byly oficiální internetové stránky komunit či organizací jimi vytvořenými, kde jsou k dispozici starší i aktuální informace o jejich aktivitách spojené s bojem proti ozbrojenému a strukturálnímu konfliktu. Dále jsou to tiskové zprávy či reportážní videa, ve kterých lze zachytit rozhovory s představiteli komunit. Dalším zdrojem byly portály zaměřené na téma ozbrojeného konfliktu v Kolumbii či kolumbijský tisk, který je k dispozici jak na internetových stránkách předních deníkủ této země, tak v digitálním archivu CINEP (Centro de Investigación y Educación Popular). Kanály internetového serveru Youtube se staly taktéž užitečným médiem zkoumaných komunit, jež svými krátkými videosoubory informují společnost o svých úspěšných zákrocích proti ozbrojenému konfliktu, problémech, názorech a záměrech. Nejinak tomu bylo i v rámci sociální sítě Facebook, kde komunity rovněž mají své stránky s př́íspěvky. Dalším zdrojem primárních dat jsou polostrukturované a narativní rozhovory poskytnuté obyvateli (zejména pamětníky, současnými či bývalými pracovníky radnic jednotlivých obcí a Asociace municipalit Ariari, AMA) povodí Ariari, kde jsem v roce 2014 uskutečnila specifický výzkum.

Nevýhodou kolumbijského tisku či výše zmíněných informačních kanálů bylo, že vytvořily mediální obraz, který ne vždy úplně odpovídal realitě. V těchto médiích se často objevovala až zidealizovaná tvrzení o formování míru na lokální úrovni a některé akty občanské rezistence jednotlivých komunit nebo jejích hlavních vůdčích osobností byly vylíčeny téměř heroicky. Z tohoto důvodu jsem se snažila udržovat odstup od těchto tvrzení a zaměřila se pouze na relevantní informace, které mi byly těmito novinovými články zprostředkovány. Nezbytnou součástí hledání informací na toto téma bylo zahrnutí veškerých dostupných primárních dat, tedy i takových, které demonstrovaly, že navzdory odporu zkoumané oblasti i nadále čelily teroru ozbrojeného konfliktu a že nelze výsledky jejich mírových iniciativ idealizovat.

4 Protesty či stávky jsou pouze jednorázovými kolektivními akcemi. Občanská společnost tak pouze reaguje na výstupy politického systému či na zvýšené násilí ze strany ozbrojených aktérů (González 2010: 41). 
Tuto skutečnost rovněž podtrhovaly zdroje sekundárního charakteru, které byly získány z dostupných ověřených pramenů, zejména $\mathrm{z}$ akademických studií a článků, a to jak od kolumbijských, tak zahraničních autorů, kteří se tematice občanské rezistence a ozbrojeného konfliktu v Kolumbii intenzivně věnují. Tyto zdroje dat mi pomohly vytvořit ucelený obraz sociální reality zkoumaných komunit, nebot poukázaly na skutečnost, že všechny tři skupiny, byt' některé z nich byly vystaveny vysokému stupni násilí (černošské obyvatelstvo Buenaventury a indiáni z Caucy) a některé méně (obyvatelé Alto Ariari), žijí v podobě míru, která byla Francisco Muñozem nazvána „nedokonalým mírem“ (paz imperfecta). V rámci tohoto typu míru jedinec, komunita či celá společnost dělá vše nezbytné pro dosažení maximální hodnoty míru, a to navzdory pokračující válce, se kterou koexistuje a učí se žít. Na základě této koncepce se mír zkoumá jako dynamický jev nacházející se v procesu konstrukce (Muñoz 2001: 11).

Z výše uvedeného vyplývá, že př́ístup, který jsem v rámci metodologie zvolila, je přístup kvalitativní, jehož základem je induktivní logika, která mi sice umožňuje nalezení společných znaků a odlišností, ale na druhou stranu dochází k nevyhnutelné redukci dat, nebot' není možné do studie zahrnout všechny dostupné informace o zkoumané problematice. Důsledkem toho je skutečnost, že závěry tohoto článku budou mít pouze pravděpodobnostní charakter. Z tohoto důvodu se budu vyhýbat jednoznačným a generalizujícím závěrům.

\section{Občanská rezistence komunit Kolumbie 1.1. Občanská rezistence afrokolumbijského obyvatelstva řeky Yurumanguí (Valle del Cauca)}

První zkoumaná skupina obyvatel pochází z povodí řeky Yurumanguí a je afrokolumbijského původu. Občanská rezistence této komunity se vyvinula na přelomu nového tisíciletí, v čase eskalujícího násilí ze strany paramilitares na tomto území. Její iniciativa je ryze lokálního charakteru a zaměřuje se zejména na obranu svého teritoria, kultury, hodnot a sebeurčení.

Zásadním mezníkem ve vztahu k občanské rezistenci byl moment, kdy černošské obyvatelstvo vyhlásilo řeku Yurumanguí za „teritorium míru a radosti“ (Territorio de Paz y Alegría). Skrze tento symbolický akt komunita vyjádřila, že nechce mít s ozbrojeným konfliktem, potažmo dalšími jevy (jako je například poškozování teritoria nadnárodními důlními společnostmi) narušujícími jejich autonomii, nic společného a že je v rámci něho politicky neutrální. Uvnitř teritoria platí striktní pravidla jako například rozhodovat o všem společně, nepoužívat zbraně, nespolupracovat s ozbrojenými aktéry či nebýt s žádným povstalcem či paramilitares v milostném vztahu (Castillo 2010: 175; Molina 2004: 261). Další praktikou je, že pokud je člen komunity podezříván ze spolupráce s ozbrojeným aktérem, je tato osoba zcela vyloučena 
z komunitních událostí jako křty, pohřby, přerozdělování ulovených ryb či udržování parcel (Domínguez 2003: 13).

Komunitní rada řeky Yurumanguí reprezentující celou komunitu je hlavním aktérem občanské rezistence. Komunita se v jejím rámci účastní fór, na kterých představuje problematiku násilí na svém území a veřejně deklaruje své požadavky. Těmi jsou např́íklad ochrana života, integrity a autonomie řeky Yurumanguí, respektování lidských práv, vyšetření škod na majetku způsobené násilím, osvobození zajatých, sociální solidarita a poskytnutí materiálních prostředků v situaci nouze. ${ }^{5}$

Komunity se rovněž v rámci boje s ozbrojeným konfliktem účastnily kampaně „Plavení se po Pacifiku“, iniciativy zaměřené na "re-teritorializaci“ řek, ${ }^{6}$ či se podílely na formulaci tzv. plánů preventivního opatření černošského obyvatelstva před vysídlením. Dalším projevem občanské rezistence bylo vytvoření tzv. kontingenčních plánů operujících na bázi včasného poplašného systému, díky kterému mezi sebou obyvatelé rríčních osad komunikují v př́ípadě nebezpečí. Plány také představují kroky k efektivní hromadné evakuaci lidí, v jejímž rámci jsou vybírána bezpečná místa k úkrytu, kde je poskytnuta i psychologická podpora obětem. Evakuací se zamezilo rovněž verbování dětských vojáků do guerilly (Castillo 2010: 175-176).

Setrvání komunit na svém teritoriu garantovala také strategie zajištění potravinové soběstačnosti, která spočívá v tom, že rodiny nesázejí pouze na svých statcích, nýbrž organizují společné brigády mingas. Díky nim komunity obnovily některé z původních plodin, které během ozbrojeného konfliktu a před vznikem rezistence zanikly (Castillo 2010: 176), či vymýtily koku v oblasti řeky. ${ }^{7}$

\subsection{Občanská rezistence mestického obyvatelstva řeky Ariari (EI Meta)}

Pod tlakem rostoucího násilí a střetů mezi ozbrojenými aktéry vznikla taktéž mírová iniciativa vesničanů pocházejících z povodí horního toku řeky Ariari. Až do poloviny 90 . let však v tomto regionu nepanovaly vhodné podmínky k usmíření společnosti, protože kvůli politickým rozporům a později kvůli ozbrojenému konfliktu nebyla možná ani vzájemná komunikace mezi

5 Actualización de la Situación en el Río Yurumanguí - Municipio de Buenaventura [online]. In: Red de Defensores no Institucionalizados. 2005 [2016-05-26].

Dostupné z: http://www.dhcolombia.info/spip.php?article103.

6 Účastníci tohoto tzv. kočovného fóra (Foro ambulante) se plavili po řekách Buenaventury až k Tichému oceánu za účelem vycvičit obyvatele těchto řek v rezistenci a obraně svého teritoria a znovuosídlit postiženou oblast (Castillo 2010: 177-178).

7 Minga Comunitaria de Erradicación Manual de Cultivos con Fines Ilícitos en el Territorio [online]. 2007 [2016-05-29]. Dostupné z: http://prensarural. org/spip/IMG/pdf/MINGA_ERRADICACION_YURUMANGUI.pdf. 
obcemi a jejími obyvateli. Bylo téměř nemožné, aby se občané obcí z Ariari svobodně pohybovali na území, která náležela sousedním municipalitám, nebot' každá z nich př́íslušela k jinému ideologickému táboru. Příkladem takto nastavených poměrů byly vztahy, které mezi sebou chovaly obce, jež se později nejvíce angažovaly v mírových procesech. El Castillo a Lejanías byly původně baštami liberálů, později táborem FARC. Cubarral a El Dorado byly obcemi náležejícími konzervativcům, poté se staly baštami paramilitares. ${ }^{8}$

Pro samotné komunity však existence rivality mezi politickými a ozbrojenými aktéry nehrála roli a svůj nesouhlas s ozbrojeným konfliktem dávaly najevo intenzivními protesty počátkem 90. let. Obyvatelé Ariari konfliktu vzdorovali ale i dalšími způsoby, a to například participací v obecních aktivitách jako přátelská sportovní utkání pořádaná starosty či kolektivní pamětí, kde si někteří z obyvatel v rámci uspořádání poutí připomínali oběti konfliktu. Se stále rostoucím násilím se však řadoví občané a jejich političtí představitelé rozhodli proti tomuto konfliktu zakročit jinou cestou a po několika společných setkáních komunit a starostů obcí tohoto regionu v roce 1998 založili Asociaci obcí Ariari. Tímto aktem dostala občanská rezistence obyvatel Ariari podobu iniciativy, jejíž hlavní úlohou je podpora rozvoje a míru, kterého se dosáhne skrze projekty generující produktivitu. Na základě realizace těchto projektů jsou tvořena pracovní místa pro domorodé komunity či jsou podporovány rodiny, které byly během ozbrojeného konfliktu vnitřně vysídleny a chtějí se vrátit do oblasti. ${ }^{9}$

Tato strategie má zaručit nejen lokální, nýbrž i regionální socioekonomický pokrok a konsolidaci míru ve společnosti. Dalším cílem je politicko-administrativní rekonstrukce kolektivních statků jako vzdělání či zdravotnictví, dále rozvoj kulturního dědictví a podpora životního prostředí a turismu. Od momentu usmíření se AMA zasazovala také o to, aby se tradiční komunitní zvyk konání brigád taktéž začal uskutečňovat „mezikomunitně“. Sdílené brigády se tak staly jedním z projektů, který AMA připravila za účelem posílit mír a společné soužití obyvatel obcí Ariari. ${ }^{10}$

Komunity prostřednictvím AMA spolupracují s kolumbijskými a mezinárodními neziskovými organizacemi, církví, obcemi, regionálními aktéry a vládou. Občanský vzdor těchto komunit však není namíren pouze na oblast ozbrojeného či strukturálního konfliktu. Komunity aktivně čelí i problémům, které mají s nadnárodní těžařskou společností Ecopetrol.

8 Premio Nacional de la Paz [online]. 2002. [2016-05-10] Dostupné z:

http://www.fes-colombia.org/premio-nacional-de-paz/.

9 Asociación de Municipios de Ariari [online]. 2008. [2016-05-10]. Dostupné z: http://web.archive.org/web/20130816061828/http://www.a-m-a.com.cohttp:// web.archive.org/web/20130816061828/http://www.a-m-a.com.co. 


\subsection{Občanská rezistence indigenního kmene Nasa (Cauca)}

Během studia dílčích projevů občanské rezistence u poslední př́ípadové studie věnované kmeni Nasa se zjistilo, že u této skupiny obyvatel jsou přítomné podobné aspekty vzdoru jako u předchozích dvou případů. Jedná se například o zabránění vnitřnímu vysídlení osob či zajištění potravinové soběstačnosti, která garantuje, že komunita kvůli nedostatku potravin nezačne kolaborovat s ozbrojenými aktéry. Pořádání velkých mingas jsou dalším projevem občanské rezistence kmene Nasa. Mingas mají dokonce i povahu politickou a konají se v rámci velkých pochodů za účelem vyjádření nesouhlasu s ekonomickým modelem neoliberalismu, se strukturálním násilím, militarizací konfliktu, globalizací11 či „parapolitikou“.

Indigenní hlídka (guardia indígena) je další známkou občanského vzdoru. Náplní tohoto útvaru je zajistit bezpečnost indigenního území resguardos, kontrolovat vnitřní a vnější pohyb příslušníků komunit a trhovců, udržovat povědomí o veřejném pořádku, bránit lidská práva, oznamovat jejich porušování či mít pod kontrolou důležité události, které jsou komunitou pořádány (pochody, kongresy, sněmy apod.). Hlídky také odstraňují instalace, ve kterých se připravují drogy, nebo zachraňují členy komunity, již se stali obětí únosů ozbrojených aktérů či byli zadrženi policií anebo armádou (Sandoval 2008: 81).

Dalším specifikem jsou asambleas permanentes, které představují specifické útočiště předem určené komunitou. $V$ případě hrozby se do tohoto místa komunita přesune a setrvá zde až do chvíle, kdy nebezpečí pomine. Místa jsou uzpůsobena základním potřebám. Najdeme zde sprchy či studny s pitnou vodou (Hernandéz 2004: 129).

Občanskou rezistenci u kmene Nasa lze ze všech tří iniciativ shledat za tu nejkomplexnější, nejambicióznější a nejvíce medializovanou. Tato komunita se snaží nejen ochránit své teritorium neboli „matku zemi“ (Madre Tierra), hodnoty, kulturu a autonomii a docílit socioekonomického rozvoje svého regionu prostřednictvím úspěšného Projektu Nasa. Usiluje totiž také o politickou emancipaci, a to nejen pro svůj kmen či veškeré indigenní obyvatelstvo Kolumbie, nýbrž i pro celou indigenní populaci Latinské Ameriky. Iniciativa tak prostupuje do úrovně lokální, regionální, státní i mezinárodní. Je také historicky nejstarší, nebot́ započala již na počátku 70. let zformováním Regionální indigenní rady Caucy (Consejo Regional de los Indígenas de Cauca, CRIC). Občanská rezistence tohoto kmene však ve svých začátcích nedosahovala takové intenzity. K rozkvětu a konsolidaci iniciativy došlo až s Ústavou z roku 1991 (Galeano 2006: 197).

11 Je nutné poznamenat, že přestože se tyto indigenní skupiny vymezují proti globalizaci, přijímají do svého diskurzu globálně reprodukované pozitivní stereotypizace eko-indiánů (viz obrana „matky země“). 


\subsection{Typologie mírových iniciativ}

Z výše uvedeného vyplývá, že některé dílčí aspekty občanské resistence zkoumané komunity sdílejí, avšak z hlediska vzniku, trvání, rozsahu a hlavně samotné podstaty se jedna od druhé odlišuje. Jednotlivé komunity se tak kromě etnických, geografických, historických, sociálních či kulturních rozdílů liší tedy i tím, že každá z nich vyvinula jiný typ občanské rezistence. Na základě typologie Catherine Gonzálezové ${ }^{12}$ jsem došla k závěru, že historicky nejmladší občanská rezistence komunit obývající řeku Yurumanguí, která vznikla v době největšího nárůstu lokálních iniciativ, typologicky nejlépe odpovídá typu „iniciativ vzdoru proti násilí a konfliktu“ (Iniciativas de Base a Favor en Resistencia a la Violencia y el Conflicto). Vesničané z Ariari zase rozvinuli občanskou rezistenci, kterou lze přiřadit do „iniciativ pro rozvoj a mír“ (Iniciativas de Desarrollo y Paz). Posledním zkoumaným př́ípadem bylo indigenní obyvatelstvo žijící na severu departementu Cauca, jejichž forma občanské rezistence má nejdelší tradici a je př́́kladem „iniciativ sociálních emancipačních hnutí“ (Iniciativas de los Movimientos Sociales Emancipatorios).

\section{Předpoklady pro vznik komunitní občanské rezistence v Kolumbii}

Během studií zdrojů bylo nalezeno hned několik možných důvodů vzniku úspěšné kolektivní akce u zkoumaných komunit, mezi které patřil například vliv církve či historická zkušenost se vzdorem proti španělské kolonizaci. ${ }^{13}$ Bylo však také zjištěno, že tyto příčiny sice mohly částečně podpořit vytvoření občanského vzdoru jedné $\mathrm{z}$ komunit, ale $\mathrm{k}$ dalším dvěma př́ípadům se vztahují jen částečně či vůbec, a tím pádem je nelze považovat za společnou proměnnou pro vznik občanského vzdoru.

Pokud je řeč o civilní rezistenci a hledání příčin jejího vzniku, lze poznamenat, že tento fenomén je jedním z projevů kolektivní akce, ke které existují teorie zaměřující se na její původ. $Z$ tohoto důvodu je vhodné začít výzkum právě u tohoto pojmu, jenž je spjatý zejména s dílem Logic of Collective Action od Mancura Olsona, podle kterého úspěch organizované skupiny, jejíž vznik je motivován ziskově, závisí na velikosti komunity (s ideálním počtem 6 až 7 členů). Uskupení musí být založeno na vztazích face to face, důvěře, společném

12 Tuto typologii jsem shledala za nejvhodnější pro můj výzkum, nebot' je v ní zahrnuto kritérium dlouhodobého vykonávání iniciativy i typologický rámec pro občanské rezistence komunitního charakteru.

13 Občanská rezistence kmene Nasa byla podle autorky Esperanzy Hernandézové mimo jiné právě důsledkem rezistence proti Španělům či působením kněze Álvara Ulcuého v této komunitě (Hernandéz 2004: 109-111). U obyvatel řeky Yurumanguí není však registrováno, že by na vznik jejich občanské rezistence měla vliv církev. Komunity z Ariari na základě působení kněze Crisanta Ramose, který se silně zasazoval o dosažení míru v této lokalitě, sice zase s kmenem Nasa tento rys sdílejí, avšak nemaji společnou zkušenost v boji s kolonizátory, nebot́ ta se vztahuje pouze k Nasa. 
přesvědčení, sdílených hodnotách či psaných recipročních normách (Cante Mockus 2005: 153-154; Olson 1965: 7, 18, 35).

Na Olsonovo dílo nahlíželi mnozí autoři kriticky. Například k jeho podmínce nutnosti existence malé skupiny pro vznik efektivní kolektivní akce vytvořil britský politolog Patrick Dunleavy protiargument, podle kterého životaschopnost skupiny dokáže růst s její velikostí, nebot' hlavní schopností velkých komunit je, že umí strukturovat své zájmy ve společnosti a přitáhnout k sobě potenciální zájemce (Gregor 2003: 6). Právě na tuto způsobilost větších uskupení bylo poukázáno v úvodní kapitole, kde v rámci pátého kritéria výběru př́ipadových studií bylo zjištěno, že všechny tři zkoumané skupiny dokázaly vyvinout iniciativu s dlouhodobou trajektorií a své zájmy strukturovat tak, aby úspěšně zakročily proti ozbrojenému a strukturálnímu konfliktu, a to navzdory velikosti, která neodpovídá Olsonovým podmínkám.

Ve studii Acción Colectiva, Violencia Política y Etnicidad en el Perú od autorů Ismaela Muñoze, Maritzy Paredesové a Rosemary Thorpové, kteří vycházeli z prací autorů Alaina Touraina či Alessandra Pizzorna, je však poukázáno na možné důvody toho, proč je větší skupina schopna vyvinout úspěšnou konstruktivní nenásilnou kolektivní akci (Muñoz - Paredes - Thorp 2009).

Na základě výzkumu tří odlišných komunit pocházejících z různých koutů Peru (Bambamarca, Espinar a Huanta) autoři přišli se závěrem, že zásadní proměnnou je etnická diferenciace a společná identita, díky kterým je problém spojený s velikostí skupiny překonán. Právě etnická diferenciace je znatelná v regionu Huanta (Ayacucho), ${ }^{14}$ kde nevznikla žádná kolektivní akce, která by vyvíjela tlak na stát či ozbrojené aktéry. Lidé z této oblasti shledávají své spoluobčany za egoisty, kteří nechtějí věnovat čas organizování komunitních záležitostí (Muñoz - Paredes - Thorp 2009: 20). Právě tento „přílišný egoismus“ podle autorů Fredyho Canteho a Antanase Mockuse znemožňuje vznik kolektivní akce (Cante - Mockus 2005: 138). K jeho demonstraci nám poslouží slova jednoho z obyvatel údolí Huanty:

„Rolníci neparticipují, je zde apatie a absence zájmu. Myslí si, že pouze když budou pracovat sami pro sebe, pokročí, ale to je nemožné. Je zde až přespř́liš egoismu a závisti. [...] Vesničané nemaji žádnou specifickou asociaci, do které by patřili. To, co mají, je nedůvěra, která je nejspíše důsledkem sociálních problémů, které zde máme. “(Muñoz - Paredes - Thorp 2009: 21)

Absence společné identity a naopak přítomnosti hluboké horizontální nerovnosti využila guerilla Světlá stezka (Sendero Luminoso, SL), která do této

14 Jedná se o indigenní skupinu obyvatel zvané chutos z vysokých hor, pěstitele misti z údolí a migranty v Huantě, z nichž mnozí představovali vykořeněné mestice bez pocitu identity a s malými př́ležitostmi ve městech (Muñoz - Paredes - Thorp 2009: 20-21). 
oblasti úspěšně ideologicky a vojensky pronikla (Muñoz - Paredes - Thorp 2009: 21). Opačným př́íkladem jsou provincie Bambamarca a Espinar, kde je etnická diferenciace nízká (a rovněž nízká horizontální nerovnost), což má za následek vytvoření společné lokální identity (ronderos ${ }^{15}$ a indígenas), vhodného prostředí k úspěšné kolektivní akci a zabránění proniknutí Světlé stezky (Muñoz - Paredes - Thorp 2009: 5).

Muñoz a kol. (2009) na základě peruánského případu dochází k závěru, že etnická diferenciace zabraňuje vytvoření identity. Naopak přítomnost pouze jednoho etnika $v$ jedné lokalitě pocit identity posiluje a tím i pravděpodobnost vzniku úspěšné kolektivní akce. I v kolumbijském př́ípadě všechny tři zkoumané komunity nejsou etnicky diferencované, tj. každá z nich v sobě zahrnuje pouze jedno etnikum, v rámci něhož je přítomna i nízká horizontální nerovnost. Z dostupných zdrojů jsme také zjistili, že jednotlivé komunity rovněž sdílejí společnou identitu: Černošští obyvatelé řeky Yurumanguí o sobě mluví jako o yurumangueños. Převážně mestické obyvatelstvo žijící v Ariari, které se nachází v údolí llanos, samo sebe chápe jako „bratry z Ariari“ (Hermanos de Ariari) či jako llaneros. Příslušníci kmene Nasa, stejně jako černošské obyvatelstvo řeky Yurumanguí, se považují za členy jiného etnika, než je to většinové, a velmi často sami sebe označují za comuneros, jejichž cílem je bránit „matku zemi“.

Z výše uvedeného lze tedy vyvodit, že při určování identity tyto tři etnicky odlišné komunity kladou důraz na prostor, ve kterém se obyvatelé zkoumaných regionů narodili, vyrůstali a žijí. $\mathrm{V}$ příští kapitole však bude rovněž zdůrazněna skutečnost, že identifikace s prostorem není jediným důvodem vzniku občanské rezistence a je nutné přihlédnout rovněž i k dalším faktorům, které jej ovlivňují.

\section{Teritorium jako zdroj identity}

\section{1. Řeka Yurumanguí jako zdroj identity pro afrokolumbijské komunity}

Občanská rezistence obyvatel řeky Yurumanguí je charakteristická tzv. „mobilizací prostoru“, která spočívá v tom, že tato komunita obratně využila prostor, který se jí během momentu hrozby útoku naskytl k útočišti. Díky říčním přítokům a četným potokům mohli uprchlíci po dobu několika týdnů hromadně zůstat ukrytí v těchto přírodních skrýších a po pominutí nebezpečí se vrátit do místa, kde žijí (Castillo 2010: 175-176). Podle Castilla tak nynější generace Afrokolumbijců včetně obyvatel řeky Yurumanguí užívá stejných praktik skrývání jako kdysi cimarrones, tedy Afričané, již povstali proti Španělům a vyzbrojeni kolektivně prchali z dolů či otrokářských velkostatků do hor nebo

15 Výraz pochází ze španělského slova rondas, tj. komunitních organizací, které vznikly původně jako patroly (Muñoz - Paredes - Thorp 2009: 13). 
těžko dostupných míst, kde vytvářeli pevnosti nazývané palenques. ${ }^{16}$ Zde představitelé různých afrických kultur spojili své hodnoty a techniky s tím, co se naučili během otroctví. Proto Castillo strategii vzdoru, kterou Afrokolumbijci v současnosti užívají v okamžiku ohrožení, nazývá „moderním cimarronismem“, nebot je tato taktika skrývání užita na základě historické zkušenosti (Castillo 2007: 155). V dnešní době však komunity dbají i na to, aby evakuace byla nejen kolektivní, nýbrž i krátkodobá, protože v opačném případě dochází k destrukci kolektivního soužití a ztrátě pout a identity, která byla vybudována na teritoriu řeky Yurumanguí (Castillo 2010: 175-176).

Právě na důležitost teritoria obyvatelé povodí řeky Yurumanguí frekventovaně poukazují, a to například v rozhovorech, které poskytli výzkumnici Karen Pfefferliové:

„Počátkem komunity je teritorium, stejně jako je prostor počátkem pro bytí. Teritorium zahrnuje vše, co člověka dělá spokojeným: vodu, minerály, rostliny, lidi, život. Je to prostor, ve kterém lidé vyrůstají a ve kterém se reprodukují. Proto je teritorium důležité.“(Pfefferli 2015: 90)

„Teritorium a kultura jsou společně velmi provázané, protože bez teritoria není kultura. Vztah mezi kulturou a teritoriem chceme udržet [...] Kultura není pouze hudba, zpěv. Kultura je půda, bytí, voda, ptáci. Tedy, pokud nemáme teritorium, nemáme kulturu.“(Pfefferli 2015: 90)

Teritorium této černošské komunity zahrnuje zejména vodní prostory, tedy řeku Yurumanguí. Castillo tvrdí, že obyvatelé z povodí řek Buenaventury vytvořili trvalé interakce se systémem řek, které zde mají determinující vliv. Toto vzájemné působení se stalo původcem vzniku „vodního prostoru“, v jehož rámci vznikl „prostor k reprezentaci“ a hluboké citové ztotožnění s řekou a tímto vodním prostorem (Castillo 2010: 166).

„Pro mě řeka znamená vše, řeka Yurumanguí je vše, prostor pro bytí, prostor, ve kterém rozvíjíme naše produktivní aktivity, kde vidíme růst naše děti, kde máme vzdělání, kde máme předky, náš život, vše [...]."(Pfefferli 2015: 90)

Řeka je podle Castilla pro afrokolumbijské obyvatelstvo Buenaventury zdrojem osobní a společenské identity a kultury a každý černošský obyvatel Tichého oceánu se chápe jako příslušník nějakého povodí (Castillo 2010: 166). Tuto tezi potvrzuje Pfefferliová, když uvádí, že například obyvatelé povodí řeky Naya jsou nayeños a obyvatelé řeky Guapi zase guapeños (Pfefferli 
2015: 90). Identifikace zkoumané komunity s řekou Yurumanguí je zase jasně prokazatelná díky následujícímu výroku jednoho z obyvatel, který je jen zlomkem podobných prohlášení:

„Pokud mluvíme o Yurumanguí, všichni zde jsme yurumangueños.

Jsme od hlavy až po paty yurumangueños. “(Pfefferli 2015: 90)

Důležitost tohoto teritoria se stvrdila v 90. letech. Po vydání Zákona 70 a jeho představení komunitám obyvatelé usilovali o přiznání půdy, která by byla oficiálně pod jejich ochranou. Na základě tohoto zákona však bylo pro přiznání půdy nutné, aby každá černošská komunita zformovala komunitní radu, která by fungovala jako vnitřní administrace (Castillo 2010: 147). Utvořením komunitní rady tak černošští obyvatelé z různých koutů Buenaventury oficiálně získali půdu, na které se mohli prostřednictvím této rady vnitřně organizovat (Castillo 2010: 178). Právě díky vybudování tohoto útvaru již při eskalaci ozbrojeného konfliktu byli obyvatelé Yurumanguí schopni efektivně a mírovou cestou zakročit.

$Z$ výše uvedeného tedy plyne, že nejen identifikace s teritoriem, nýbrž i utvoření komunitní rady, které bylo vyžadováno státem, bylo zásadní pro občanskou rezistenci černošského obyvatelstva řeky Yurumanguí.

\section{2. Řeka Ariari a los Ilanos jako zdroj identity pro mestické obyvatelstvo}

Teritorium je taktéž důležité pro komunity z druhé případové studie. Zdrojem identifikace je pro ně řeka Ariari, jejíž úrodná půda byla důvodem, proč rodiny osadníků začaly toto území obsazovat. Sám současný výkonný ředitel asociace AMA Luis Alberto Rodríguez upozorňuje na tuto skutečnost:

„Sice je pravda, že původní osadníci pocházeli z jiných departementů jako Tolima, Huila či Cundinamarca, ale jejich současní potomci regionu Ariari mají již jiný zdroj identifikace, a tím je povodí řeky Ariari a údolí llanos, které se může pyšnit nesmírně úrodnou půdou. “17

Vzorným příkladem toho, co pro rolníka půda znamená, je rovněž prohlášení vyhoštěných vesničanů, kteří se během ozbrojeného konfliktu vrátili zpět do povodí této řeky:

„Práce je základ našeho života, našeho rolnického bytí.

[...] Půda je náš zdroj práce, kvůli ní bojujeme, kvůli ní se organizujeme, kvůli ní se vracíme."18 
Půda je tedy jediným zdrojem obživy a pokroku pro tuto společnost a její produkty je nutné směňovat či prodávat, a to i mimo svoji obec. To však nebylo v Ariari před př́měřím možné. Tento fakt potvrzuje administrativní pracovnice AMA Neissan Romerová:

„Lidé tu byli zavření. Nikam téměr nemohli. Nemohli ani do vedlejší vsi prodávat své zboží, produkty vypěstované na své půdě. Uzavření míru a ukončení ozbrojeného konfliktu, se kterým obyvatelé neměli nic společného, bylo důležité, ale stejně tak to bylo zapotřebí i kvưli ekonomickým důvodům a rostoucí bídě. "19

Úrodná půda je pro vesnické obyvatele zdrojem ekonomické moci, na jejímž základě lze dosáhnout zisku a materiálních statků. Po prostudování katastru půdy v El Meta zjistíme, že na území, kde občanská rezistence vznikla, tedy obce El Castillo, Lejanías a El Dorado, jsou majoritně přítomny malé statky, minifundia, v Lejanías i mikrofundia, v menším zastoupení statky středního rozsahu. Latifundie zde nejsou. ${ }^{20}$

Na rovnou distribuci půdy v Ariari v rozhovoru poukazuje bývalá starostka El Castilla Laura Romerová:

„Je zde mnoho lidí, mnoho majitelů parcel, bývalí osadníci na velmi úrodné půdè, která je z mého úhlu pohledu velmi dobře distribuovaná." ${ }^{21}$

Výrok Romerové potvrzuje v rozhovoru Rodríguez:

„Společný zájem rolnických rodin o ukončení ozbrojeného konfliktu a započetí využívání výhod plynoucích z produkce byl jedním ze zásadních faktorů vzniku AMA. Je zde mnoho malých pěstitelů ovoce a zeleniny, kteři pracují na svých parcelách, jež získali v období kolonizace regionu Ariari.“

Podle Olgy Jarramillové právě mikrofundia, minifundia a malé statky jsou předpokladem ke vzniku tzv. junt komunitní akce (juntas de acción comunal, JAC), protože velkostatkáři, ačkoliv mají největší ekonomickou moc, se nepodílejí na komunitních záležitostech a ani v nich nerozvíjejí kolektivní akci (Jarramillo 2009: 242-245). 
JAC vznikly v období obsazování půdy v departementu El Meta v 50. letech a tvořily se z popudu politiky státu a politické strategie Národní fronty.22 Ta měla za cíl začlenit komunity do procesu realizace vlastních infrastrukturních děl a služeb na svém teritoriu a dosáhnout tak jejich co největšího zapojení do politik státu (Palacios 1995: 256). Zkušenost rolníků organizovat se je tedy již letitá. V rámci JAC se konají pravidelné schůze s komunitou, setkání tvořená ženami či výše zmíněné brigády pořádané za účelem zlepšení produktivity či výstavby cest a silnic.

Laura Romerová poukazuje na jeden velmi důležitý aspekt těchto junt, a to je jejich zásadní role při mírových procesech:

„Pro utvoření míru byla zásadní aktivita junt komunitní akce, prostřednictvím kterých vesničané vystupují. V El Castillo jsou tyto junty velice dobře organizované a snažily se tuto vyhrocenou situaci způsobenou ozbrojeným konfliktem řešit. Prezidenti junt ve jménu komunit chodili na radnici s žádostí, aby starosta začal jednat. Prostřednictvím junt se lidé scházeli i na náměstí, aby protestovali proti násilí a dalším nedostatkům.“

Kněz Crisanto Ramos, nynější Sekretář obětí z El Meta, který během ozbrojeného konfliktu pracoval s komunitami, poukazuje na jejich důležitou roli v usmiřovacím procesu v Ariari:

„My [církev, starostové] jsme otevřeli dveře, ale byli to vesničané, kteří riskovali život, aby se mohli účastnit usmiřovacích setkání. Vraceli se za soumraku, když tato cesta byla nebezpečná. Pochyby, strach, neustálý tlak ozbrojených skupin, které se snažily sabotovat proces, byly nepřetržité.” (Martínéz Escallón 2010: 57)

Z výše uvedených informací můžeme vyvodit, že i v tomto případě byly komunitní orgány (konkrétně JAC obcí El Castillo, El Dorado, Lejanías a Cubarral) důležitým faktorem pro vznik úspěšné občanské rezistence, v rámci které komunity vystoupily proti ozbrojenému konfliktu.

\subsection{Madre Tierra jako zdroj identity pro indigenní obyvatelstvo}

Teritorium má nesmírný význam i pro kmen Nasa, podle něhož půda není pouhým územím vhodným pro chov a pěstování, z kterého pramení zisk. Země je pro Nasa la madre (matka), původ všeho a všech, místo pro život, práci i smrt.

22 Roku 1957 Konzervativní a Liberální strana uzavřely dohodu o vzniku Národní fronty, která měla obnovit demokracii v zemi prostřednictvím schématu sdílené moci (Palacios 1995: 256). 
Ochrana tradice, jazyka a kulturních rysů, které jsou úzce provázané s tímto teritoriem a předky, je hlavním důvodem k rezistenci (Molina 2004: 259).

„Země je pro nás to největší, nejposvátnější. Země je

pro nás matkou." (Caycedo et al. 2007: 60)

„Tradičně Nasa byli vždy silně spojeni se zemí, protože když se jeden narodí, jeho pupeční šňůra je zahrabána do země vedle ohniště. Tento akt jedince silně spojí s teritoriem, zde spočívá jeho identita, $v$ tulpa, ${ }^{23} v$ ipkwe se tvoři běh života a př́běh tohoto jedince Nasa. "(Caycedo et al. 2007: 60)

Právě proto je jednou z hlavních priorit kmene Nasa dostat zpět půdu, která jim byla vyvlastněna a putovala do rukou velkostatkářů. Tento kmen rovněž usiluje o to, aby na jeho území neoperovali ozbrojení aktéři, kteří svými aktivitami rozvíjejí formy násilí, které indigenní obyvatelstvo nutí k vysídlení.

Nasa představuje nejorganizovanější skupinu indigenní populace v Kolumbii. Příčiny přítomnosti takto vysoké organizační schopnosti u tohoto kmene vysvětluje Myriam Galeanová, podle které je nutné hledat důvody v historických procesech transformace teritoria této komunity (Galeano 2006: 45).

Členové kmene Nasa žijí v resguardos, jejichž původ se nachází v politice Španělské koruny. I přes skutečnost, že prostřednictvím tohoto útvaru Španělé indigenní obyvatelstvo kontrolovali a vykořistovali, má pro nativní obyvatelstvo tato formace obrovský význam. Představuje pro něj totiž tmelící prvek, který posiloval a posiluje jejich příslušnost ke kolektivu. Pomocí resguardos se vytvořilo prostředí, kde indigenní komunity mohly sdílet společnou minulost a kolektivní vlastnictví, které zde zbylo po jejich předcích. Mohly tady také posilovat a chránit svoji kulturu, autonomii a komunitní organizaci. Tento celek, i když už v menším počtu, setrval na severu Caucy až do začátku 70. let, kde mělo na základě agrární reformy dojít k jeho úplnému zrušení. Na odpor vưči tomuto transformačnímu procesu se vytvořil CRIC, díky kterému se zachoval nejen tento útvar, nýbrž i integrita teritoria, v rámci kterého se domorodí obyvatelé mohli i nadále organizovat, a to i politicky prostřednictvím další instituce, jíž jsou cabildos (Galeano 2006: 45).

Důvodem toho, proč zrovna indigenní populace ze severu Caucy se stala tak úspěšná v rezistenci, je tedy skutečnost, že tento departement zůstal na okraji transformací ekonomických a společenských struktur, které se v Kolumbii uskutečnily na sklonku 19. století. Zatímco ve zbytku země

Posvátný prostor okolo ohniště, kde se rituál odehrává. Pueblo Nasa erradicó 200 mil matas de coca como ejercicio de autonomía y control territorial [online]. In: Asociación de Cabildos Indígenas del Norte del Cauca [online]. 2015 [2016-05-15]. Dostupné z: http://anterior.nasaacin. org/index.php/informativo-nasaacin/nuestra-palabra-kueta-susuza-2013/7745-pueblo-nasaerradic\%C3\%B3-200-mil-matas-de-coca-como-ejercicio-de-autonom\%C3\%ADa-y-control-territorial. 
se s resguardos skoncovalo, v Cauce se tento útvar (a to zejména resguardo Toríbio) udržel a velkostatky pokračovaly v původní jednoduché ekonomické struktuře, kde př́íslušníci indigenních komunit fungovali jako terrazgueros, kteří byli povinni platit velkostatkáři formou roboty za účelem moci setrvat na svém teritoriu (Galeano 2006: 45). Zachování koloniálních struktur a systému encomiendy má tedy své pozitivní důsledky pro uskutečňování kolektivní akce a zásadně přispělo i ke vzniku občanské rezistence kmene Nasa. ${ }^{24}$ Je nutné rovněž poznamenat, že, podobně jako v případě černošského obyvatelstva řeky Yurumanguí, i zde ústava z roku 1991 a na jejím základě vzniklý Zákon 134 v roce 1994 pomohly kmeni Nasa k realizaci cílů a vzniku efektivní občanské rezistence, nebot' do politického života implantovaly mechanismy lidové participace (Molina 2004: 304).

\section{Závěr}

V předchozí kapitole jsme zjistili, že řeka Yurumanguí je pro černošské obyvatele zdrojem osobní identity a kultury, což bylo také důvodem vzniku kolektivní akce, v rámci které tato komunita chtěla své teritorium ubránit. Velkou roli však také hrála historická zkušenost hledání nových teritorií během vzdoru proti Španělům, Ústava z roku 1991 a Zákon 70, prostřednictvím kterého započal proces oficiálního přiznání půdy černošským komunitám v 90. letech. Obyvatelé z řeky Yurumanguí i jiných řek obce Buenaventura tak museli pro zisk půdy vytvořit komunitní rady, které měly sloužit k vnitřní administraci území a poté i k efektivní mobilizaci v okamžiku nebezpečí ze strany ozbrojených aktérů.

U obyvatel z Alto Ariari můžeme zpozorovat podobné tendence. Vedle vazby na obývané teritorium byl rovněž důležitým faktorem zisk půdy během kolonizace departementu El Meta v období La Violencia, kdy obyvatelé různých koutů Kolumbie unikali před násilím občanské války. Pro lepší správu svého území a dosáhnutí podpory od státu bylo nezbytné, aby rolníci vytvořili junty komunitní akce. Koncept JAC byl tedy výsledkem politik v té době vládnoucí Národní fronty, což je skutečnost, která je mnohými autory kritizována, a to z důvodu vzniku klientelismu, avšak na druhou stranu je nezpochybnitelným faktem, že právě junty se staly hlavními aktéry mírových procesů v tomto regionu.

Historická zkušenost s rezistencí proti dobyvatelům a také zachování systému encomiendy v severní Cauce až do počátku 70. let mělo zase pozitivní vliv

24 Hypotézu Galeanové potvrzuje fakt, že stejný kmen žijící v jiných departementech (např. Tolima či Huila) neprojevil tak intenzivní občanskou rezistenci jako právě kmen Nasa z Caucy, jehož iniciativa byla vůbec první v Kolumbii. Občanský vzdor nativního obyvatelstva v jiných departementech Ize tak označit spíše za spill-over effect, nebot krátce po prvním impulzu vzešlém od kmene Nasa (vznik CRIC), začaly vznikat podobné organizace (Consejo Regional Indígena de Huila, CRIH a Consejo Regional Indígena de Tolima, CRIT). 
na konzervaci teritoriální integrity indigenních resguardos a identity kmene Nasa. Udržením tohoto útvaru se zefektivnila činnost politických orgánů zvaných cabildos, jejichž prostřednictvím tato komunita může prezentovat své požadavky, které má vůči státu a ozbrojeným aktérům. Ústava z roku 1991 rovněž, podobně jako u Afrokolumbijců, posílila politickou participaci u této menšinové komunity.

Z výše uvedených informací vyplývá, že jedním ze společných faktorů, na základě kterých zkoumané komunity vyprodukovaly fenomén občanské rezistence, je vazba na teritorium. Na důležitost identifikace s prostorem pro vznik kolektivní akce v Kolumbii poukazuje Carlos Medina, který tvrdí, že pro indigenní, rolnické a černošské komunity koncepce teritoria nabyla nové dimenze a již není pouze fyzicko-geografickou jednotkou, nýbrž dosáhla také ekononomicko-sociálního rozměru, který je úzce propojen s kulturou, historií a politikou. Na základě tohoto spojení se tak formuje pocit identity a ztotožnění se s prostorem (Medina 2013: 23). Právě prostor a teritorium se podle Carlose Castilla proměnily v důležité faktory pro vznik kolektivní akce a sociálních hnutí Latinské Ameriky. Jeho tvrzení se zakládá na známé tezi Johna Agnewa, podle kterého se sociální hnutí dnes již nepojí výlučně se sociální tř́́dou, ale objevují se i jiné dimenze jako místo a teritorium a s ním právě i tendence identifikace s prostorem (Castillo 2010: 166). Tuto hypotézu rovněž potvrzuje Arturo Escobar, který za příklad uvádí kolumbijské komunity u pobřeží Pacifiku či Zapatisty v Chiapasu (Escobar 2001: 150).

V rámci analýzy historických zdrojů a rozhovorů se dále zjistilo, že úspěšné zformování občanské rezistence ve třech zkoumaných oblastech bylo zaprríčiněno rovněž příznivými historickými a politickými procesy, které jsou v kontextu vzniku sociálních hnutí označovány jako tzv. struktura politických př́ležitostí (Political Opportunity Structure, POS). Výsledkem těchto procesů bylo dosažení integrity teritoria a vznik či zachování komunitních útvarů (Komunitní rada, JAC, resguardos), díky kterým došlo k lepšímu spravování daných území, zefektivnění organizačních schopností komunit a jejich lepší mobilizaci v momentě nutnosti, tedy i během eskalace ozbrojeného konfliktu. Větší možnost politické participace v Kolumbii, jež byla dána Ústavou z roku 1991, je rovněž důležitým článkem konceptu politických př́ležitostí.

Skutečnost, že tyto dva výše zmíněné faktory, tedy teritoriální identita a POS, má za př́ičinu vznik konstruktivní kolektivní akce u mnou zkoumaných komunit, potvrzuje výrok dalšího teoretika v oblasti kolektivní akce, a to Alberta Melucciho. Carlos Manuel Rodríguez Arechavaleta píše, že Melucci v období, kdy paradigmatem pro vznik společenských hnutí byla právě POS, poukázal na fakt, že sociální hnutí nelze redukovat pouze na reakci na podněty vycházející z politického systému. Tento autor kombinuje vliv POS s dalším faktorem, který napomáhá vzniku kolektivní akce, a to právě se sdílenou identitou a společnou kulturou jednotlivých komunit (Rodríguez 2010: 26). 
Za klíčové aspekty lze však rovněž považovat i absenci etnické diferenciace a výrazných sociálních nerovností v každé ze zkoumaných komunit, což potvrzuje hypotézu Ismaela Muñoze, který ten samý fenomén zkoumal u komunit v Peru. ${ }^{25} \mathrm{Z}$ rozhovorů rovněž vyplývá, že pro vznik úspěšné konstruktivní kolektivní akce je velmi klíčová také spravedlivá distribuce půdy. Tento faktor je zdůrazněn rovněž Muñozem a kol.. ${ }^{26}$ avšak neodlučitelně spjatý je hlavně s myšlenkami Timothy Wickhama-Crowleyho, které tento autor představuje ve své knize Guerrillas and Revolution in Latin America. ${ }^{27}$

Vzhledem k povaze této práce, která zkoumá pouze tři případy kolektivní akce, však není vhodné na základě odpovědi na výzkumnou otázku vytvářet všeobecně platnou hypotézu, nebot zde není k dispozici dostatečné množství případů, jejichž prostřednictvím bych mohla potvrdit nebo vyvrátit pravdivostní hodnotu výše zmíněných výstupů. Za zvážení tedy stojí myšlenka zkoumání dalších případů občanské rezistence komunit Kolumbie, a to napříč etnicitou a na základě stejných kritérií, se kterými jsem pracovala doposud. V ideálním př́ípadě by bylo možné zkoumat občanskou rezistenci na úrovni komunit i v jiných státech Latinské Ameriky a ověřit tak nejen faktor teriroriální identity, nýbrž i faktor politický, jenž je spojený s teorií struktury politických př́ležitostí, která se v zemích Latinské Ameriky v různých historických obdobích liší. V rámci Kolumbie se POS stala jednou z příčin vzniku silné občanské společnosti, jejímž plodem je civilní rezistence proti strukturálnímu a ozbrojenému konfliktu. Pravděpodobně i z tohoto důvodu je tento fenomén mezi kolumbijskými i světovými badateli velmi populárním tématem a vhodným předmětem pro výzkum.

\section{Únor 2018}

25 Tento aspekt však nesouvisí pouze s venkovskými komunitami a Ize jej vysledovat i u komunit v městském prostředí.

26 Skutečnost, že byla půda v Espinaru po násilných bojích navrácena do rukou indigenních komunit a v Bambamarce parcelizace půdy proběhla ještě před nevydařenou agrární reformou z 60. let, měla za následek vznik konstruktivní kolektivní akce. Naopak u komunit, které podobným procesem neprošly, se uchylovaly k opačným tendencím, a to k násilné kolektivní akci (viz Ayacucho) (Muñoz - Paredes - Thorp 2009: 9). Guerrilly, ústřední představitelé násilné kolektivní akce, neměly v Peru tak velkou podporu, a to mimo jiné pro vyšší počet držitelů malých pozemků. V Kolumbii naopak byly bojůvky silnější z důvodu podpory squatterů (pronajímatelé půdy) a sharecropperů (migrující za sezonními pracemi) (Wickham-Crowley 1992: 92-130). 


\section{Literatura}

Cante, Fredy - Mockus, Antanas. 2005. Acción política no-violenta, una opción para Colombia. Bogotá: Universidad Colegio Mayor de Nuestra Señora del Rosario.

Castillo, Luis Carlos. 2007. Etnicidad y nación: El desafío de la diversidad en Colombia. Cali: Universidad de la Valle.

Castillo, Luis Carlos. 2010. Acción colectiva y resistencia negra en el norte del Cauca y sur del Valle. In: Desigualdades étnico raciales, acción colectiva, etnicidad y resitencia en el norte del Cauca y sur del Valle. Cali: Universidad de la Valle: 125-193.

Caycedo Sánchez a kol. 2007. Pueblo Nasa: identidades y expresiones de resistencia política. Bogotá: Universidad Nacional de Colombia.

Domínguez Mejía, Marta Isabel. 2003. Los procesos de resistencia al conflicto armado y al desplazamiento forzado por parte de pobladores rurales afrocolombianos en el municipio de Buenaventura. In: Informe final del concurso: Movimientos sociales y nuevos conflictos en América Latina y el Caribe. Buenos Aires: Programa Regional de Becas CLASCO.

Escobar, Arturo. 2001. "Culture sits in Places: Reflections on Globalism and Subaltern Strategies of Localization". Political Geography 20 (2): 139-174.

Galeano Loyano, Myriam. 2006. Resistencia indigena en el Cauca: Labrando otro mundo. Bogotá: Consejo Regional Indígena del Cauca.

González, Catherine. 2010. Iniciativas de paz en Colombia. Civilizar 10 (18): 35-53. Bogotá: Universidad Sergio Arboleda.

Gregor, Martin. 2003. Vzestup a pád národů. Praha: MegaPrint.

Hernandéz Delgado, Esperanza. 2004. Resistencia civil artesana de paz. Experiencias indígenas, afrodescendientes y campesinas. Bogotá: Pontificia Universidad Javeriana.

Jarramillo Gómez, Olga Elena. 2009. El ejercicio del poder en las juntas de acción comunal rurales: El caso del municipio de Sonsón, Antioquia. Bogotá: Pontificia Universidad Javeriana.

Martínéz Escallón, Margarita. 2010. „El arduo camino de la reconciliación.” Crónicas: Premio nacional de la paz. Bogotá: Fridrich Ebert Stiftung en Colombia: 53-67.

Medina Gallego, Carlos. 2013. Comunidades y territorios en resistencia sur de Bolívar, bajo Cauca y nordeste antioqueño. Bogotá: Universidad Nacional de Colombia.

Molina Valencia, Nelson. 2004. Resistencia comunitaria y transformación de conflictos. Un Análisis desde el conflicto político-armado de Colombia. Barcelona: Universitat Autónoma de Barcelona.

Muñoz, Francisco Adolfo. 2001. La paz imperfecta ante un universo en conflicto. Granada. Instituto de la Paz y Conflictos. Universidad de Granada.

Muñoz, Ismael - Paredes, Maritza - Thorp, Rosemary. 2009. Acción colectiva, violencia política y etnicidad en el Perú. In: Acción colectiva, desigualdad y conflicto en la sociedad peruana: Una aproximación. Lima: Pointifícia Universidad Católica del Perú: 99-55.

Olson, Mancur. 1965. The Logic of Collective Action: Public Goods and the Theory of Groups. Cambridge: Harvard University Press.

Palacios, Marco. 1995. Entre la legitimidad y la violencia. 1875-1994. Bogotá: Editorial Norma. Pfefferli, Karen. 2015. El río es vida. Lund: Lund University.

Rodríguez Arechavaleta, Carlos Manuel. 2010. De la estructura de oportunidades políticas a la identidad colectiva. Apuntes teóricos sobre el poder, la acción colectiva y los movimientos sociales. Espacios Públicos 13 (27): 187-215. Toluca: Universidad Autónoma del Estado de México.

Sandoval Forera, Eduardo Andrés. 2008. La guardia indígena Nasa y el arte de la resistencia pacífica. Bogotá: Fundación Hemera.

Wickham-Crowley, Timothy. 1992. Guerrillas and revolution in Latin America. A Comparative Study of Insurgents and Regimes since 1956. Princeton: University Press. 